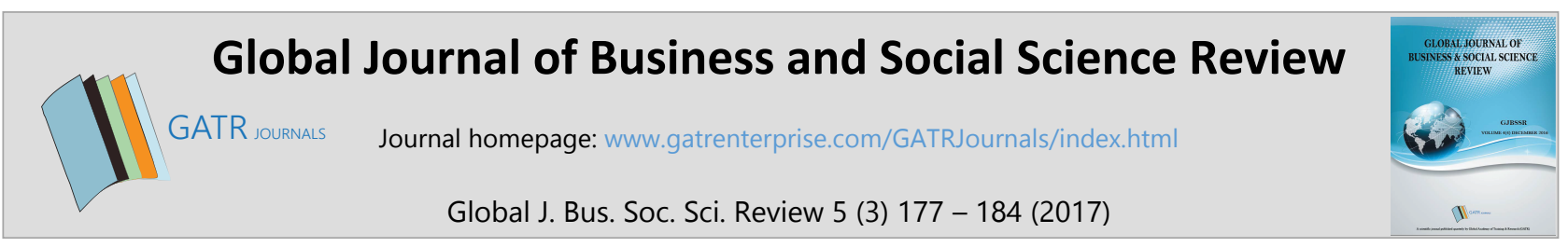

\title{
The Gap Between Regulations and Their Implementation on the Fulfilment of ECOSOC Rights: Study on Village People in Mount Merapi Central Java, Indonesia
}

\author{
Aloysius Wisnubroto ${ }^{1 *}$ and Johanes Widijantoro ${ }^{2}$ \\ ${ }^{1}$ CSHD, University of Atma Jaya Yogyakarta, Indonesia
}

\begin{abstract}
Objective - This research was aimed at firstly, uncovering how people in Mount Merapi meet their daily needs without government aids and secondly, finding the solutions to narrow the gap between regulations and the implementation of the people's ECOSOC rights.

Methodology/Technique - The research conducted in 2012 showed that based on local wisdom values, hundreds of households rejected the government's policy related to the relocation. The policy was issued by the government for disaster risk reduction. Their villages were categorized as disaster-prone areas and banned to be inhabited. Because of their refusal, as a consequence, they did not receive any government aids.

Findings - On one hand, the government is constitutionally required to protect and fulfil its citizens' ECOSOC rights; but, on the other hand, the government may not provide aid due to the existence of regulation prohibiting people living in disaster-prone areas. As a result, people rely on social capital and local wisdom to fulfil their daily needs, and to narrow the gap, the government should implement the concept of living in harmony with disaster. Based on the discussion in the previous sections, it can be concluded as follows: First, regulation and its implementation, which were based on positivism doctrine, had led the government to not fulfilling the ECOSOC rights of the people who rejected to be relocated.
\end{abstract}

Novelty - The research suggests strategies for improving ECOSOC rights

Type of Paper: Review.

Keywords: Disaster; Government Policy; ECOSOC Rights; Mount Merapi.

JEL Classification: Q51, Q54, Q58.

\section{Introduction}

This paper was part of the field research conducted by Research Team of Center for the Study of Human Rights and Democracy (CSHD), University of Atma Jaya Yogyakarta. The study focused on issues where regulations became an obstacle for the State in fulfilling the people's economic, social and cultural (ECOSOC) rights especially for the people living in Mount Merapi in Central Java, Indonesia.

Following the catastrophic Mount Merapi's eruption at the end of 2010 (in which hundreds of home destroyed), the government issued the Action Plan for the Rehabilitation and Reconstruction of Areas Post-

\footnotetext{
* Paper Info: Received: November 11, 2016

Accepted: June 5, 2017

* Corresponding author:

E-mail: qw.aloy@gmail.com

Affiliation: CSHD, University of Atma Jaya Yogyakarta, Indonesia
} 
Merapi Eruption Disaster in Yogyakarta and Central Java from 2011 to 2013 (hereinafter referred to as Merapi Action Plan 2011-2013). One of the key policies in this action plan was to relocate residents living within Directly Affected Areas. The areas consisted of two regencies: Sleman and Klaten. However, not all residents accepted the government's relocation policy. At least there were more than 461 households in Sleman and more than 130 households in Klaten refused to be relocated. They resettled in their old villages with their own efforts, although, their previous villages were declared as "forbidden area" and banned for dwelling by the government (Wisnubroto et al., 2012, p. 122 \& 125).

The relocation policy stipulated in the Merapi Action Plan 2011-2013 was based on regulations as follow: Law No. 24 of 2007 on Disaster Management, Sleman Regency Regulation No. 12 of 2012 on Spatial Planning, and Klaten Regency Regulation No. 11 of 2011 on Spatial Planning. Based upon these regulations, the government was determined to implement relocation program to the people living in Mount Merapi. In order to avoid the risk of violating regulations, the government refused to provide any assistance or facilities to the people who rejected to be relocated. Even, the people who rejected to be relocated were considered as "outlaws". However, the people remained to resettle in Disaster Prone Zone (DPZ) / Directly Affected Area (with the highest level of disaster impact). As a result, they did not obtain their basic rights, such as the right to education, the right to health, the right to a decent life and so on. Thus, the problems to be addressed were: (1) How the people who rejected to be relocated fulfill their daily needs without government's assistance; and (2) What the solutions to narrow the gap between regulations and the implementation of economic, social, and culture rights are.

Although it appeared that the problem emerged from the existence of regulations in the form of a series of positive legislation as the legitimacy of the relocation policy, but the people's rejection rested more on arguments that were in the realm of meta-judicial. Thus, in order to answer those problems, the implementation of normative jurisdiction assessment method was not adequate, and as a consequence, the socio-legal approach was chosen as a method of study in this paper. By conducting in-depth interview towards residence in some villages in Mount Merapi and supported by managing focus group discussion with key persons, problems and facts related to this research could be collected and analyzed.

\section{Positivism Doctrine in Regulation Versus Socio-Cultural Reality}

Positivism is a doctrine which teaches that the law should have a figure that is not within the realm of the meta-judicial, but in the real that is objective (visible and legible firm and clear) (Wigjosoebroto, 2002, p.96). The doctrine of law positivism views the law in a concrete form that is the regulations (legislation) as a rule which is plenary so it should be executed and enforced as such or in accordance with the text (la bouche de la loi). Nonet and Selznick (1978, p. 54) stated that the essence of modern law as an autonomous legal type (autonomous law) with a unique character: separate from politics, the rule of law supports the model regulations, the procedure is the heart of law and respect for the law is understood as a perfect adherence. From a historical perspective, this type of positive law emerged because it was needed to regulate modern society in the 19th century. Alvin Toffler in his book "The Third Wave" wrote that in the 19th century, society (European context) experienced a change from the type of agrarian society into "industrial society". Positive law model which guaranteed the aspect of legal certainty was in accordance with the type of industry people who think rational logical, structured and bureaucratic (Wisnubroto, 2010, p. 22-33).

Positivism doctrine as stated previously also appeared on the implementation of the Merapi Action Plan 2011-2013 through relocation policy for people who live in DPZ which was Directly Affected Area by Mount Merapi's eruption. The relocation policy was based upon the Map of Area Affected by Mount Merapi's Eruption and Cold Lava, which on May 31, 2011, was signed by five ministers (including the Minister of Energy and Mineral Resources) and two governors from Yogyakarta and Central Java. The map was an integral part of the Merapi Action Plan 2011-2013. According to Article 32 of Law No. 24 of 2007 on Disaster Management, the Government has the authority to establish disaster-prone areas as restricted areas. In certain 
circumstances, the Government may revoke or reduce the ownership rights of everyone to an object (including the right to land in the affected area).

The map of DPZ having broad implications should have been formulated and established by a credible institution that understands the characteristics of disasters in its region. In reality, the Map of Area Affected by Mount Merapi's Eruption and Cold Lava (May 31, 2011) used as the basis of DPZ after Merapi's eruption in 2010 was not made by Regional Disaster Management Agency (RDMA). The map was made by National Disaster Management Agency (NDMA) through relevant technical agencies namely: Agency for the Assessment and Application of Volcanology Technology, Center for Volcanology and Disaster Mitigation, Ministry of Energy and Mineral Resources, and the Directorate of Spatial Planning Ministry of Public Works.

Besides problems related to the competency of the institution in mapping DPZ, the regulation is not participatory in nature. During the formulation process, the government actually consulted with some leaders and local government officials who were considered to represent the people of the affected areas. However, this model of "represented participation" was not able to accommodate the concept and hopes of the people who inhabited the affected areas. In the process of policy making, "representative participation" model resulted in different concepts. Moreover, the authority of policy making that should be given to RDMA was taken over by NDMA so that the government policy was far from the hopes of people in Mount Merapi (Gutomo, 2011, p. 13).

In addition, the government apparatus' way of thinking tended to be positivistic as follow: firstly, government's officials viewed the regulation as a perfect law to be obeyed absolutely; secondly, the central government's apparatus, on the basis of science and volcanology technology, pretended to understand disaster management better than the local community; thirdly, dialogue for conflict resolution with people who rejected relocation tended to be less qualified since the government only accommodated the aspirations of citizens who support the relocation policy. It proved that the government's behavior was very dominated by positivistic way of reasoning. Satjipto Rahardjo (Dimyati, 2004) state that positivistic is affected by reasoning tradition which empowers rational and logic. It has atomizing, masinal, deterministic and linear characteristics.

The people living in Mount Merapi believed that everything in the Merapi's ecosystem was perceived as "living". The belief in the supernatural realm was used as a framework for the people's adaptation to Mount Merapi (Triyoga, 1991, p. 115). For hundreds of years, people living in Mount Merapi became very familiar with the nature or character of this volcano. Through spiritual intelligence and sensitivity to the signs of nature, people knew when Mount Merapi would erupt and they knew how to deal with it. It could be proved that during 2010 eruption, which was very powerful, none of the people who inhabited in Mount Merapi - which then designated as DPZ - became a victim. The people interpreted the eruption of Merapi as part of the natural tradition to distribute gifts from the Creator to humans. This was evident from the fertility of the agricultural land in Mount Merapi after the eruption.

The engagement with Mount Merapi with all the socio-cultural aspects became one of the reasons for the people's rejection of the relocation policy. Furthermore, there were also other reasons, both essential and technical, namely: first, livelihoods of the people were farmers-breeders and thus required large farms (not just $100 \mathrm{~m} 2$ land including the building such as in the new location); second, the livelihoods of farmers-breeders required extensive land. The people did not believe that the government could provide large areas for relocation because the available land was very limited. Therefore, the land at the top slopes remained necessary for agriculture and livestock; third, public facilities such as school buildings, building places of worship (mosque) were still available and were still able to function; fourth, there was still water source. The people just needed to repair facilities damaged by the eruption; fifth, the land which was relatively wide in the old villages will in future be passed on to their children. The $100 \mathrm{~m} 2$ land in permanent housing relocation will not be enough to be inherited; sixth, the people was already possessing disaster response. It was proved that there were no casualties in the eruption of 2010; seventh, the people had been able to live a normal life with their post 2010 eruption livelihoods, even they had harvested; eighth, the boundaries between lands owned by the people in 
the three furthest top villages were still visible, so it was easy for people to recognize their own land; ninth, a paved road that connects their uphill village to the downhill villages still existed.

On top of that, the people wanted the government not to implement the relocation policy for those already able to survive and reconstruct their lives and their livelihoods after the disaster. It proved that even when the government did not provide assistance, the people managed to restore their life using the social capital and even after five years from disaster the life of the people in DPZ were much better (Based on direct surveillance on July 31, 2015).

\section{Human Rights Violation by the Government and People's Strategy in Fulfilling Their Ecosoc Rights}

Empirical facts which could be seen to date were that the people who rejected to be relocated resided back in the DPZ. These people suffered from discriminatory treatment that led to human rights violations. The State, in this case, Sleman's and Klaten Regency's government had created inequities even though it was based upon the regulation.

Some facts that showed human rights violations against people who rejected to be relocated in DPZ of Mount Merapi were as follow: First, there was no effort from the government to repair the water supply system which was heavily damaged by the eruption. Water is a basic requirement for human beings especially for people on the mountain slopes who are living as farmers-breeders (Supply of water in Kalitengah Lor and Kalitengah Kidul Villages was finally assisted by a Non-Government Organization. The aid was not wanted by Sleman Regency's Authority because it was considered as an obstruction for relocation process). Second, the demand for electricity in the Glagaharjo Village (Sleman) was supplied from Balerante Village (Klaten). The installation was done directly by National Electricity Company (not through the efforts of the government). Third, the people were forced to build their own homes which were heavily damaged by a pyroclastic flow. The rebuilding was supported by social capital such as cultural cooperation and assistance from non-government institutions. Fourth, the former school building could still be used, but after 2010 eruption, the government, through Klaten's Department of Education, prohibited teachers to teach in those schools. Fifth, the permanent housing concept for relocation did not correspond to the socio-cultural life of the people who live on the slopes of Merapi. Without being realized, coercion for people to change their pattern of life had happened. It meant depriving the people of their rights in retaining their tradition and developing their socio-culture. Sixth, by establishing DPZ as an occupancy free region, it would eliminate the region's population map which resulted in the loss of the rights of people who resettle in the area.

The actions of the government could be categorized as human rights violations, in the form of violation of economic rights, especially the rights to favorable working conditions (Article 7 ICESCR), violation of social rights, especially the right to a decent living (Article 11 ICESCR), and the violation of cultural rights, especially the rights to education. As we know that ECOSOC rights emphasized on demands for the State to provide protection and assistance (providing welfare to individuals) (Palupi, 2011) so that the government's attitude towards the people who rejected to be relocated could be regarded as a violation of human rights "by omissions". Ironically, Sleman Regency supported by Sleman's Parliament considered its actions (which led to violations of human rights) as something normal because it was in accordance with the legislation ("Jogja" Daily Newspaper, September 2, 2013). Accordingly, Sultan HB X, as the Governor of Yogyakarta Special Province did not accept the petition from people in DPZ with a reason of not violating the law, even though Sultan understood that there was a powerful socio-cultural factor that made them remain in the forbidden zones (Tribun Jogja). Knowingly or not the attitude of the Governor of Yogyakarta will perpetuate discriminatory treatment and violations of basic rights for the people who inhabit DPZ. The government's actions which were interpreted as "sanctions" for "offenders" seemed to be fair, but it was only in the form of formal justice. In other words, legal justice is not always synonymous with social justice.

Although they did not obtain aid from the government, the people who rejected relocation and chose to stay in DPZ zone maintained their life through their own efforts. The following were the strategies employed by 
the people to maintain their life until they could be self-sufficient in fulfilling the economic and social rights (Wisnubroto et al., 2015).

The people of Klaten Regency started their life by using their savings, support from family and relations, cooperation works and using various building materials and household utensils that they could still use to start a new life. They did the effort to fulfill the basic needs through the following stages as follow: first, they cleaned up the land and collected materials and equipment that could still be used; second, they seek help from family, neighbors, and relations to gain support for the rebuilding of their homes, either in the form of money or materials. In addition, they utilized savings and grants from various donors and volunteers; third, they set up a makeshift home for shelter for the family whom they move from the temporary housing; fourth, the first and main financial support came from the "blessing of sand" that they collected and sold. According to Mr. Jainu, the chief village in Klaten regency, they did so in groups, each group consisted of 4-5 people. Within a day they were able to collect sand manually 4-5 trucks per day from early morning until late in the evening, with revenues of approximately 400-500 thousand rupiahs; fifth, when the land recovered a few months later, then they started planting their gardens. Crops were used for daily needs, and sold to earn income; sixth, with the savings from the sale of sand, they could buy cows, in addition to the cattle they still had the results of the exchange of dead livestock by the government. The cow would be bred when the grass had widely grown in their village; seventh, to obtain additional income, they were active in various business activities: services (e.g., carpenters, drivers, etc.) and trade (vegetable collectors, grocery store, etc.). Of course, various other income could still be earned: civil servants, private sector workers, land owner, and help from family members outside the area. Exceptions also occurred in the previous pattern, for example, there were people who did not want to depend on the result of sand and stones, because mining activities were deemed as environmentally unfriendly, so they tried to survive as farmers and breeders.

After fulfilling their basic needs, the people managed to meet their secondary and tertiary needs. They repaired their house, bought a motorcycle and 4-wheeled vehicles, purchased a truck or pick-up truck to transport sand/stone or vegetables and grass. They could also buy vegetable seeds to be planted and sold. With such enormous income, some people could even buy a house in the safer area. So, if there is a threat of eruption, they will use their own homes as a place for evacuation. Nevertheless, the establishment of residents' area into DPZ became barriers for people to develop their business by using bank mortgage since banks did not want to receive land assets in DPZ as a mortgage for business loans. Thus, in almost 5 years, they are gradually improving their lives and fulfilling their needs.

A similar portrait also occurred in Sleman Regency. They gradually met daily needs by using various resources: (1) savings and miscellaneous supplies; (2) sand / stones; (3) garden (vegetables and grass); (4) cattle; (5) trade (grocery, food and beverages, vegetables); (6) services (driver, tourist guide at tourist sites); and (7) civil servants and village's apparatus. With income from various resources, they could gradually meet their basic needs, repair their houses and buy transportation and telecommunications devices.

\section{How to narrow the Gap between Regulations and Efforts of Fulfilling Ecosoc Rights}

Based on the discussion in the previous sections, it could be concluded that the conflict situation which led to the gap between the government' point of view and the people's socio-cultural perspective in Mount Merapi could be described as follows: (Wisnubroto et al., 2012) 
Table 1. To narrow the Gap between Regulations and Efforts of Fulfilling Ecosoc Rights

\begin{tabular}{|c|c|c|}
\hline \multicolumn{3}{|c|}{ MOUNT MERAPI'S DISASTER RISK } \\
\hline The Government & vs & The People \\
\hline Establishes and Applies policies & vs & Respond the policies \\
\hline Relocation & VS & Reject Relocation \\
\hline Bases/argument & vs & Bases/argument \\
\hline $\begin{array}{r}\text { Regulations } \\
(\text { Rule \& Logic) } \\
\end{array}$ & vs & Local Wisdom (Rule \& Behavior) \\
\hline $\begin{array}{r}\text { Law No. } 24 \text { of 2007; } \\
\text { Law No. } 26 \text { of 2007; } \\
\text { Sleman Local Regulation about Regency's Spatial } \\
\text { Planning; } \\
\text { Klaten Local Regulation about Regency's Spatial } \\
\text { Planning; etc. }\end{array}$ & vs & $\begin{array}{l}\text { Value system \& socio-cultural system in } \\
\text { understanding Mount Merapi } \\
\text { The concept of Living in Harmony With Disaster } \\
\text { Risk }\end{array}$ \\
\hline $\begin{array}{r}\text { Map of Disaster Prone Region } \\
(D P Z \& D A A)\end{array}$ & vs & Instinct \& Experience \\
\hline $\begin{array}{r}\text { Hard Science } \\
\text { (Rational/Science) Volcanology Science }\end{array}$ & vs & $\begin{array}{l}\text { Soft Science (Sense) Mount Merapi’s } \\
\text { Mythologies }\end{array}$ \\
\hline Reduction & vs & Enrichment \\
\hline Life is salvation of souls & vs & Life is sustainable livelihood \\
\hline \multicolumn{3}{|c|}{ PEOPLE LIVE IN PROSPERITY } \\
\hline
\end{tabular}

From the previous scheme, it could be seen that government's policy was in accordance with the people's will, that was, the realization of a prosperous community life after Mount Merapi's eruption. However, there were differences in viewpoint which resulted in conflicting principles, arguments, and steps in achieving that goal. The government insisted that relocation was the best policy to rescue the people who inhabited DPZ (Wisnubroto et al., 2012) While people of the villages on top slopes of Mount Merapi steadfastly refused to be relocated due to the belief that their lives could not be separated from the soil and the environment which they had inhabited since many years ago until present. The government based their arguments on: firstly, regulations as a type of modern law having the characteristics of legality; and secondly, recommendations based on the study of science and volcanology technology (hard science). Meanwhile, the people based their arguments on nature and social reality in their area of living. Furthermore, their consideration was based on the wisdom of cultural, social capital and empirical experience (soft science). Finally, the root of this conflict was caused by the actions of the government which was influenced by the positivism doctrine and local wisdom. The conflicts were originated from different perspectives and arbitrary behavior that ultimately led to human rights violations.

The solution which could be offered in order to overcome the problems was the application of progressive law introduced by Satjipto Rahadjo (professor of the sociology of law from University of Diponegoro, Indonesia). Progressive law emerged as a reaction to the weakness of modern law that came from positivism doctrine. The authors would not describe the "theory of progressive law" at length in this paper (since now there is a great deal of literature that discusses the progressive law), but the authors would just take the essence of the teachings of progressive law that rests on the philosophy saying that "the law is for humans" meaning that: First, the law prioritizes factors and the role of man above the law. Second, the law is pro-fairness, propeople and pro-poor. Third, the law frees man from the norm which is based on rules and procedures. Fourth, the law should be accompanied by efforts that go beyond the usual standards (doing the utmost). Fifth, the law capitalizes conscience which includes the attitude of empathy, compassion, dedication, sincerity, dare implemented by the spiritual quotient $(2006,2009 ; \& 2011)$.

The settlement of the problem must be done by establishing a concept of disaster management. The concept must be accepted by all parties. That process has been done and has resulted in the concept of "living in harmony with disaster". Juridical constraints such as various regulations and policies that were inconsistent 
with the concept of living in harmony with disaster and a complicated process for legal amendment must be addressed in a way that was free from the shackles of narrow positivistic reasoning. Progressive legal principles that are very suitable for the needs of this "release" are as follow: first, the regulation and its implementation must not be counterproductive in achieving the welfare of society. Policies which caused human rights violations were counterproductive and therefore should be reviewed or a breakthrough was needed to overcome; second, in accordance with the concept of "living in harmony", there should also be resettlement policy which was adjacent to the relocation policy and was enforced as a free choice for the people as legal principles for human beings; third, the "life" in the context of disaster relief was not just meant as an act of lifesaving, but it should be interpreted as a sustainable livelihood (Ashley \& Carney, 1999); fourth, practicing law was not just implementing the rule but must also be accompanied by conscience. Where was the conscience if due to differences in point of view, people who rejected to be relocated (as victims of the eruption) were branded as outlaws, so that human rights violations experienced by the people obtained justification as sanctions; fifth, in fulfilling human rights for the people, the government must go beyond their minimum liability (doing the utmost). In addition to providing basic needs' assistance and facilities for people in DPZ, the government must progressively strive to increase the capacity of the people in the face of disaster's risks. In short, this conflict phenomenon, which emerged from regulation, must be addressed by using comprehensive concept and human rights perspective. In this case, the spirit of progressive law (with its principles which understand the law as "holistic human system") became an alternative way to practicing law appropriately in order to support the concept of "living in harmony with disaster risks" and the concept of "Disaster Resilient Regions" as part of Merapi Action Plan 2011-2013 program.

\section{Conclusion}

Based on the discussion in the previous sections, it can be concluded as follows: First, regulation and its implementation, which were based on positivism doctrine, had led the government to not fulfilling the ECOSOC rights of the people who rejected to be relocated. In the absence of aid and facilities from the government, the people who became victims of Mount Merapi's eruption had to meet their daily needs on their own. They relied on social capital and local wisdom, namely, utilizing the remaining property, building a life with a culture of mutual cooperation, taking advantage of the sand from the eruption for economic capital. Second, in order to fulfill human rights and social justice for the people who rejected relocation and resettled in DPZ on Mount Merapi, the concept of comprehensive solutions with human rights perspective was needed. In this case, the spirit of the progressive law with its principle "law for man" and the principle of liberating the law from "mechanistic rules system" to "holistic human system" was seen as an option to bridge the gap between government policy and people's principles. The way of practicing law which reconciles conflict by applying the concept of "living in harmony with disaster" reiterated the Nation's obligations in fulfilling the basic rights of citizens and increasing the capacity of citizens in the face of disaster that would ultimately lead to the achievement of welfare and social justice.

\section{References}

Ashley, C., \& Carney, D. (1999). Sustainable livelihoods: Lessons from early experience (Vol. 7, No. 1). London: Department for International Development.

Dimyati, K. (2004). Legal Studies: Search, Liberation and Enlightment (Ilmu Hukum: Pencarian, Pembebasan dan Pencerahan), Surakarta: Muhammadiyah University Press.

Gutomo (2011). Strategic of Relocation and Resettlement Policy in Directly Affected Areas of Mount Merapi Eruption (Strategi Kebijakan Relokasi dan Permukiman Kembali (Resettlement) di Area Terdampak Langsung Erupsi Gunung Merapi), Policy Paper, Jakarta: Population Research Center-LIPI.

Nonet, P., \& Selznick, P. (1978). Law and society in transition: Toward responsive law. Transaction Publishers. Rahardjo, S. (2006). Hukum Dalam Jagat Ketertiban(Law and the World Order). UKI Pres, Jakarta. 
Satjipto Rahardjo, P. (2009). Hukum Progresif: Sebuah Sintesa Hukum Indonesia (Progressive Law: A Synthesis of Indonesian Law). Yogyakarta: Genta Publishing.

Safitri, M. (2011). Satjipto Rahardjo dan Hukum Progresif: Urgensi dan Kritik [Satjipto Raharjdo Progressive law: Urgency and Crtitics]. Jakarta: Epistema Institute dan HuMa.

Triyoga, L. S. (1991). Manusia Jawa dan Gunung Merapi: persepsi dan kepercayaannya. Gadjah Mada University Press.

Wisnubroto, A. (2010). Quo vadis tatanan hukum Indonesia (Quo Vadis Indonesia Legal Order). Universitas Atma Jaya Yogyakarta.

Wisnubroto, Al., Handoyo, C., Widijantoro, J., \& Widiarto, R.S. (2012). Response and Regulation Accomodation towards Aspiration based on Local Wisdom of Citizens Who Refuse Relocation in Cangkringan Distric, Sleman, Yogyakarta and Kemalang District, Klaten, Central Java (Respon dan Akomodasi Regulasi terhadap Aspirasi Berbasis Kearifan Lokal Warga Penolak Relokasi di Kecamatan Cangkringan Sleman DIY dan Kecamatan Kemalang Klaten Jawa Tengah), Yogyakarta: PSHD-UAJY.

Wisnubroto, Al., Pramono, S.A., Widijantoro, J., Sanjaya, I Putu S. (2015). Mapping Strategy Fulfillment Economic Rights and Victims of Mount Merapi eruption Culture: A Case Study in Rural Communities Relocation Repellent Balerante (Klaten) Central Java and Village Glagaharjo (Pemetaan Strategi Pemenuhan Hak-hak Ekonomi dan Budaya Korban Erupsi Gunung Merapi: Studi Kasus Komunitas Penolak Relokasi di Desa Balerante (Klaten) Jawa Tengah dan Desa Glagaharjo (Sleman), CSHD-UAJY.

Wignjosoebroto, Soetandyo (2002). Law: Paradigm, Method, and its Problem Dinamic (Hukum: Paradigma, Metode dan Dinamika Masalahnya), Jakarta: ELSAM \& HUMA.

Jogja Daily Newspaper (2013, September) <http://www.harianjogja.com/baca/2013/09/02/-zona-bahaya-merapipemkab-sleman-tegas-living-in-harmony-masih-wacana-443387> 